\title{
Effects of Soil Amendment with Chinese Herbal Medicine on Cassava Growth and Rhizosphere Microbial Diversity
}

\author{
jinshan wu \\ Hainan University \\ yijie zhang \\ Hainan University \\ jingwen ha \\ Hainan University \\ longyan tan \\ Guizhou University \\ honggang wang \\ Hainan University \\ yingxue jia \\ Hainan University \\ ruoyan wang \\ Guizhou University \\ Yinhua chen ( $\nabla$ yhchen@hainanu.edu.cn ) \\ Hainan University
}

\section{Research Article}

Keywords: Cassava, Chinese medicine compound preparation, Growth characteristics, Soil bacteria, Soil fungi

Posted Date: September 24th, 2021

DOI: https://doi.org/10.21203/rs.3.rs-907435/v1

License: (c) (i) This work is licensed under a Creative Commons Attribution 4.0 International License. Read Full License 


\section{Abstract}

This study aimed to determine the effects of different dosages of Chinese herbal compound soil amendment on cassava growth and rhizosphere microbial diversity. In this study, Cassava SC8 growth was determined under four treatments. The growth was promoted by the application of the Chinese herbal compound soil amendment powder and agent. After 240 days of treatment, we measure its height, diameter of the stem, maximum perimeter of cassava, tuber number, weight of single tuber, yield per hectare, the mineral elements in cassava, the ash content in starch and the microbial diversity in the soil. Compared with the control group, the height, diameter of the stem, maximum perimeter of cassava, tuber number, the weight of a single tuber, yield per hectare in the treatment groups all show increase, and the application of $1200 \mathrm{~kg}$ of Chinese herbal compound soil amendment per hm² (T2) had the strongest positive effect on the cassava growth. As for the water content of tubers, that of T2 decreased by $5.96 \%$ compared with T4, while no substantial difference among other groups. The Fe content in T2 decreased by $29.46 \%$, and $\mathrm{Zn}$ in T3 increased by $39.48 \%$, while the content of other metal ions in four treatments showed no substantial difference. At the same time, the experiment also found that, as bacterial abundance in soil, Streptophyta dominated in T2, and Fimbriimonas is a unique genera of T2. In addition, the abundances of Nocardioides and unclassfied_Spartobacteria in the T2 were greatly considerable than other treatment groups. As fungal abundance in soil, after treated with different concentrations, the composition of soil fungi differed greatly among the groups, and the samples at different concentrations contained more than 20 species of unique bacteria. At the genus level, compared with the control group, the relative abundance of unclassfied_Chaetomiaceae in the treatment group was considerably reduced, and the relative abundance of Psathyrella in the T1 increase substantially. We speculates that these advantages and the existence of bacteria and fungi can affect rhizosphere soil microorganisms, further improve soil effective nutrients and enzyme activities, thereby affecting the growth and physiological indicators of cassava plants.

\section{Introduction}

Cassava (Manihot esculenta Crantz) is one of the three key tuber crops in the world, known as the "king of starch," "special crop" or "underground granary." Moreover, it is the food crop in tropical and subtropical areas, mainly used for starch production, and also used in medicine, textile production and energy generation ${ }^{1}$. However, cassava has long been regarded as a crude crop. During the planting process, farmers often apply only a small amount of basal fertilizer or leave the soil unfertilized ${ }^{2}$, which negatively affecting the yield and quality of cassava.

Soil amendments always be treated as a valuable source of nutrients for impoverished agricultural soils, with the potential to improve crop quality. In the recent decades, studies have shown that soil amendment can effectively facilitate plant growth and quality, including the yield, emergence rate, aboveground biomass and other physiological indicators $3,4,5$ and improve rhizosphere microbial diversity ${ }^{6}$. Wu ${ }^{3}$ applied an environmentally friendly soil amendment (acid soil amendment and nutritive acid soil amendment) developed from agricultural waste resources and humic acid to cassava planting fields in Hainan Province and found that it could substantially improve the yield and other agronomic traits of cassava. In addition, other studies have found that the application of soil amendment applied in lettuce (Lactuca sativa L.), ginkgo (Ginkgo biloba L.) and walnut (Juglans regia) can promote their growth and improve various physiological indexes $7,8,9,10,11,12$.

Microorganisms in the soil are highly diverse and abundant ${ }^{13}$. These microbes play a pivotal role in the establishment of microbial diversity. Recent studies has proved many different biotic or abiotic factors will cause the change of microbial community structure and composition which may influence crop production in certain aspects ${ }^{14,15}$. In the last years, the application of organic matter (OM) in the agricultural production always in form of applying crop residues, manure, compost into soil, which has gained much attention on develop soil amendments as a sustainable approach for the reutilization of these byproducts ${ }^{16,17,18,19}$. For example, livestock manure-derived amendments can be very useful to improve the quality of agricultural soil, as they increase the content of soil OM and stimulate microbial activity and biomass, thus enhancing crop yield ${ }^{20}$.

Although there has been considerable research on the improvement of plant physiological indexes promoted by soil amendments, the effect of Chinese herbal medicine on the growth of cassava has not yet been reported. Taking cassava as the research object, which are the optimal combination selected by multi-site and multi-crop plot tests for many years on crops such as tomatoes, strawberries, tea and Radix pseudostellariae in Guizhou from 2018 to 2020. In this study, we use residue of Chinese herbal medicine as raw materials, making them into powder and water as organic soil amendment. Artemisia artemisiae and A. argyi are common herbs in powder and water. Artemisia carvifolia and Lonicera japonica were applied as the main raw material preparation for the production of crop root soil powder (a local substitute for conventional organic fertilizer or chemical fertilizer), intended to act as a fertilizer and also assist in the prevention and control of plant diseases and insect pests.

Artemisia annua is widely distributed in all parts of China, and its medicinal parts are the dry ground parts. This plant has a considerable growthpromoting effect, and the appropriate concentration of extract can regulate the growth of rice, wheat and other crops, and improve seed vigor and activities of various enzymes ${ }^{21,22}$. Chen also found that a variety of lipid-solvent and water-impregnated compounds in $A$. annua can regulate and control plant growth ${ }^{23}$. Artemisia annua mother liquor ethanol extract compound has allelopathic effect on wheat, and the appropriate concentration has a strong promoting effect on wheat seed germination ${ }^{24}$. Flavonoids are secondary metabolites of plants and have a variety of important biological functions ${ }^{25}$. According to previous studies by the project team, flavonoids are included in the chemical components of bacteriostatic agents and antiviral water agents ${ }^{12,26}$, which may affect the microbial diversity in the soil. 
In this study, the residue of A. artemisiae and A. argyi were used to prepare water spraying agent on cassava leaves, and the soil improvement powder was also applied to roots as organic soil amendment. We found that the combination of the water and powder was shown to improve the growth, yield and quality of cassava. This study also aimed to determine the effects of different dosages of soil amendment powder on cassava growth indexes and microbial diversity. The results of this study are intended to provide support for improving cassava cultivation technology and raising production and planting level.

\section{Materials And Methods Test materials}

The experimental cassava SC8 was planted in the agricultural science base of Hainan (ridges $12 \mathrm{~m}$ in length, $1.2 \mathrm{~m}$ in width, and $0.6 \mathrm{~m}$ between ridges; $0.5 \mathrm{~m}$ between plants). When the plant height was about $60 \mathrm{~cm}$, the plant was topdressed with Chinese herbal compound soil improvement powder and agent. The Chinese herbal compound powder was prepared with residue of multiple herbs such as A. carvifolia, Artemisia argyi and Sophora flavescens, according to the method described by Wang ${ }^{12}$, and the agent was prepared by the method described by Zheng ${ }^{26}$. The powder and agent were made up according to the formula of Chinese medicine, which was reported by Wang ${ }^{12}$. The raw powder of Chinese medicinal materials residue prepared as an agent was crushed into crude medicinal material powder ( $\leq 40 \mathrm{~mm})$, which was mixed with hulled wheat bran and roasted for $45 \mathrm{~min}$. The mixture turned slightly yellow and was then applied to the soil powder. The organic matter content of the powder was $90 \%$, total nitrogen, phosphorus and potassium content was 7.2\%, and pH was 5.8, according to the test by Guizhou Provincial Quality Inspection Institute, which was the optimal combination selected based on multi-site and multi-crop plot tests for many years on crops such as tomatoes, strawberries, tea and R. pseudostellariae in Guizhou from 2018 to $2020^{12,26}$. All materials were provided by Guizhou Yichuan Biotechnology Co., Ltd.

Experimental research and field studies on plants complies with relevant institutional, national, and international guidelines and legislation

\section{Experimental equipment}

Experimental equipment included an electronic balance, ruler, tape measure and caliper.

\section{Test methods}

Three treatments relating to the herbal compound dosage and one control were set in this experiment. The treatments were as follows: $900 \mathrm{~kg} / \mathrm{hm}{ }^{2}$ soil amendment powder (topdressing) + agent (T1); $1200 \mathrm{~kg} / \mathrm{hm}^{2}$ soil amendment powder (topdressing) + agent (T2); $1500 \mathrm{~kg} / \mathrm{hm}{ }^{2}$ soil amendment powder (topdressing) + agent (T3); and an unfertilized control (T4).

Chinese herbal compound soil amendment fertilizer was used as topdressing, and no fertilizer was applied to the control. The agent were mixed, diluted 15 times and then sprayed on cassava regularly (every 10-15 days).

The compound soil amendment powder was used as topdressing, and a distance of application was $15 \mathrm{~cm}$ between each seedling to avoid fertilizer burn. After fertilizer application, $2.0 \mathrm{~kg}$ of compound antibacterial agent and antiviral agent was taken and diluted 15 times (1 kg of water solution for each $15 \mathrm{~L}$ volume sprayer), and then filled with clear water. The spray was applied once every 10-15 days. During spray irrigation, the nozzle of the sprayer was put to the root and sprayed for about 3 seconds, and then applied to the leaf surface. The amount of reagent sprayed for each fertilizer application shall comply with the following standards: foliar spray with water droplets on the leaf surface but do not fall.

Determination of physiological indexes and bacterial diversity after treatment with chinese herbal compound soil conditioner

After 240 days of plant treatment, measure its height from the base of the plant with a tape measure near the ground; use a caliper to measure the diameter of the stem at the base; The weight of a single tuber is measured using an electronic balance. Three replicates were set for each index of each treatment, and each replicate had 5 plants. Yield per hectare is calculated from the yield per plant.

Quality treatment of cassava tubers: Choose different treatments, moderately sized and mature tubers, rinsed with pure water, dry them, and cut them into small pieces, two samples were taken from the pieces, and repeat 3 pieces for samples each treatment. One sample was put in an oven at $60^{\circ} \mathrm{C}$ for 3 days, and then its water content was measured. The other was wrapped in tin foil and quickly placed in dry ice to measure the diversity of the bacteria. The rhizosphere soil was taken from the soil $0.5 \mathrm{~cm}$ near the tubers, put in a kraft paper envelope and put in dry ice for testing. Each treatment was repeated 3 times.

Root tuber starch content and nutrient composition determination: Use ICPOES to determine the mineral elements in cassava; quickly determine the ash content in cassava starch based on near-infrared spectroscopy.

The experimental data were statistically analyzed using WPS 2019, and the variance and correlation were analyzed using SPSS 20.0.

The diversity of cassava rhizosphere bacterial flora was determined by Shenggong Bioengineering (Shanghai) Co., Ltd.

\section{DNA Extraction and Illumina MiSeq Sequencing}


Genomic DNA was extracted from freeze-dried soil sample with E.Z.N.ATM Mag-Bind Soil DNA kits. Quantifications of bacterial 16S rDNA and fungal ITS rDNA were performed using the Qubit3.0 DNA detection kits. We selected the bacterial V3-V4 regions of the 16S rRNA gene using the individual barcoded primers 341F/805R and fungal 1-2 regions of ITS gene using the individual barcoded primers ITS1F/ITS2R for high-throughput sequencing analysis ${ }^{27}$. The Polymerase Chain Reaction amplification conditions were as follows, the reaction mixtures in each tube contained $1-\mu \mathrm{L}$ of target DNA, $15-\mu \mathrm{L}$ of $2 \times$ Taq master Mix $(2 \times$, TaKaRa, Japan), 1- $\mu \mathrm{L}$ of forward and reverse primers, and $30-\mu \mathrm{L}$ of sterile distilled water, with a total volume of $48-\mu \mathrm{L}$. A two-step PCR approach was as follows: Thermal cycler conditions for primary PCRs consisted of 3 min at $93^{\circ} \mathrm{C}$, followed by 5 cycles of $30 \mathrm{~s}$ at $94^{\circ} \mathrm{C}, 20 \mathrm{~s}$ at $45^{\circ} \mathrm{C}$ and $30 \mathrm{~s}$ at $65^{\circ} \mathrm{C}$, followed by 20 cycles of $20 \mathrm{~s}$ at $94^{\circ} \mathrm{C}, 20 \mathrm{~s}$ at $55^{\circ} \mathrm{C}$ and $30 \mathrm{~s}$ at $72^{\circ} \mathrm{C}$, and final extension it for 5 min at $72^{\circ} \mathrm{C}$. Secondary PCRs comprised of denaturation for $3 \mathrm{~min}$ at $95^{\circ} \mathrm{C}$, followed by 5 cycles of $20 \mathrm{~s}$ at $94^{\circ} \mathrm{C}, 20 \mathrm{~s}$ at $55^{\circ} \mathrm{C}$ and $30 \mathrm{~s}$ at $72^{\circ} \mathrm{C}$, and final extension it for $5 \mathrm{~min}$ at $72^{\circ} \mathrm{C}$. After PCR amplification, the amplicons were quantified. Next, samples were loaded onto an Illumina MiSeq highthroughput sequencing platform for paired-end sequencing ${ }^{28}$, and sequenced by Sangong Bioengineering (Shanghai, China). Illumina MiSeq raw sequences were processed and analysed using the Quantitative Insights into Microbial Ecology (QIIME) software package (version 1.8.0) ${ }^{29}$. After the PCR products of the target fragments of soil microbes were sequenced, the effective sequence was processed for quality control, splicing, and precise removal of impurities to obtain an optimized sequence. The quality-filtered sequences were subsequently clustered in Operational Taxonomic Units (OTUs) at 97\% similarity and annotated using the Ribosomal Database Project (RDP) and the Silva bacteria database to determine the phylogeny and relative abundance of the OTUs ${ }^{30}$.

\section{Bioinformatics and Statistical Analysis}

The R software (version 4.0.2) was used for bioinformatics analysis, and some plots were generated using the "ggplot2" package. Use the "vegan" package to calculate the number of microorganisms, abundance and diversity index based on the 16S and ITS OTU table. The relative abundances of bacteria were expressed as percentages. T test or two-way analysis of variance (ANOVA) with the Duncan's multiple range test was performed for multiple comparisons to determine the substantial differences of the total number and a-diversity index of bacteria and fungi in the rhizosphere soil, and use Excel 2019 software is visualized. All statistical tests performed in this study were considered significant at $p<0.05$ using SPSS version 20.0 software. Differences were considered significant at P-values less than 0.05 . The effects of different dosages Chinese herbal medicine on microbial core and unique OTUs in each soil environment were analyzed according to the method provided by Zhao ${ }^{31}$ and Shade and Handelsman ${ }^{32}$. The OTUs that consistently appeared in the three biological replicates of all soil samples were regarded as core microbiomes, while the some OTUs that only presented in the three biological replicates of one soil samples were considered as unique microbiomes. These results were visualized using the Venn diagrams drawn. Principal coordinates analyses (PCoA) based on Bray-Curtis distance were used to evaluate the differences among microbial communities of different rhizosphere soil. Perform Hierarchical cluatering analysis based on the beta diversity distance matrix. Linear discriminant analysis (LDA) and effect size (LEfSe) analyses were performed using the LEfSe tool ${ }^{33}$. Differences in rhizosphere bacterial abundance were analyzed by LDA EffectSize (LEfSe). LEfSe analysis uses the Kruskal-Wallis rank sum test to detect considerably different abundances and generates LDA scores to estimate the effect size (threshold: $\geq 2$ ).

\section{Results}

\section{Effects of different amendment concentrations on basic physiological indexes Effects of different amendment concentrations on cassava plant height}

Tall cassava plants can use light energy more efficiently than shorter plants, thus improving the quality and yield of tuber blocks. Table 1 describes the effects of different concentrations on growth indexes of four groups. As shown in Table 1, there was a substantial difference in plant height of cassava plants treated with different dosage of modified preparation. All three treatments showed a considerable increase, among which T2 was highest, with an increase of $24.22 \%$ compared with T4. Relative to T4, T1 and T3 increased by $15.70 \%$ and $12.56 \%$, respectively; however, there was no significant difference between the two groups, as shown in Fig. $1(P<0.05)$.

Table 1

Effects of different concentrations on growth indexes of cassava

\begin{tabular}{|c|c|c|c|c|c|c|}
\hline Treatment & $\begin{array}{l}\text { Plant } \\
\text { height }(m)\end{array}$ & $\begin{array}{l}\text { Diameter of stem } \\
\text { base }(\mathrm{cm})\end{array}$ & $\begin{array}{l}\text { Maximum perimeter of } \\
\text { cassava }(\mathrm{cm})\end{array}$ & $\begin{array}{l}\text { Cassava } \\
\text { number }\end{array}$ & $\begin{array}{l}\text { Weight of cassava per } \\
\text { plant }(\mathrm{kg})\end{array}$ & $\begin{array}{l}\text { Yield per hectare } \\
(\mathrm{kg})\end{array}$ \\
\hline $\mathrm{T} 1$ & $\begin{array}{l}2.58 \pm 0.09 \\
b\end{array}$ & $2.38 \pm 0.15^{b}$ & $20.55 \pm 2.00^{c}$ & $\begin{array}{l}9.30 \pm 1.34 \\
b\end{array}$ & $3.42 \pm 0.74^{b}$ & $\begin{array}{l}30827.64 \pm \\
4131.66^{a b}\end{array}$ \\
\hline $\mathrm{T} 2$ & $\begin{array}{l}2.77 \pm 0.12 \\
a\end{array}$ & $2.60 \pm 0.14^{a}$ & $24.90 \pm 3.68^{a}$ & $\begin{array}{l}9.82 \pm 2.09 \\
a\end{array}$ & $4.57 \pm 0.95^{a}$ & $\begin{array}{l}34158.90 \pm \\
4717.86^{a}\end{array}$ \\
\hline T3 & $2.51 \pm 0.13$ & $2.27 \pm 0.16^{b c}$ & $22.62 \pm 2.26^{b}$ & $\begin{array}{l}8.20 \pm 2.10 \\
b\end{array}$ & $3.34 \pm 0.61^{b}$ & $\begin{array}{l}26895.60 \pm \\
1470.01^{b}\end{array}$ \\
\hline $\mathrm{T} 4$ & $\begin{array}{l}2.23 \pm 0.15 \\
c\end{array}$ & $2.17 \pm 0.29^{c}$ & $19.10 \pm 1.88^{c}$ & $\begin{array}{l}7.70 \pm 1.06 \\
b\end{array}$ & $2.01 \pm 0.26^{c}$ & $\begin{array}{l}25169.68 \pm \\
2698.92^{b}\end{array}$ \\
\hline
\end{tabular}


Note: The values in the table are mean \pm standard deviation; Different lowercase letters in the same column represent significant differences at the $\mathrm{P}<0.05$ level.

The treatments were as follows: $900 \mathrm{~kg} / \mathrm{hm} 2$ soil improvement powder (topdressing) + bacteriostatic agent + antiviral agent (T1); $1200 \mathrm{~kg} / \mathrm{hm} 2 \mathrm{soil}$ improvement powder (topdressing) + bacteriostatic agent + antiviral agent (T2); $1500 \mathrm{~kg} / \mathrm{hm} 2$ soil improvement powder (topdressing) + bacteriostatic agent + antiviral agent (T3); and an unfertilized control (T4).

\section{Effects of different amendment concentrations on plant base stem diameter}

The stem diameter of cassava can directly reflect the growth potential of cassava. Generally speaking, the taller plants with strong stems have a strong growth potential, and the yield of tuber blocks is also high. As shown in Table 1 and Fig. 1, the diameter of the base stem of cassava was substantially different among plants treated with different dosages of modified preparation. All three treatments showed thickening, with T1 and T2 increased significantly relative to $\mathrm{T} 4$, by $9.68 \%$ and $18.82 \%$, respectively (Pख0.05). The increase of T3 was $4.61 \%$, and it was not significantly different from that of T4.

\section{Effects of different amendment concentrations on yield parameters}

Tubers are the main product of cassava, and thus the main way to obtain economic benefits; we found that soil amendments can substantially improve the quality and yield of cassava tubers. Table 1 and Fig. 2 show that the maximum tuber circumference, tuber number, yield per plant and yield per hectare of the three treatments all increased after soil amendment. Among the four indexes, T2 showed the most considerable increase by $30.37 \%, 27.53 \%, 127.36 \%$ and $35.71 \%$, respectively. The effect of T3 was the worst, with increases of $18.43 \%, 6.49 \%, 66.17 \%$ and $6.86 \%$,

respectively. Under T1, the four indexes increased by $7.59 \%, 20.78 \%, 70.15 \%$ and $22.48 \%$, respectively. According to the weight of tuber per plant, the per-hectare yield of T1, T2, T3 and T4 was $30827.64,34158.90,26895.60$ and $25169.68 \mathrm{~kg}$, respectively.

The maximum tuber block circumference was significantly increased in T2, T3 and T4, but T1 was not significantly increased (P凶0.05). In terms of the number of tuber, the increase of T1 and T3 was not substantial except for T2. The yield per plant in all three groups was significantly increased, but there was no significant difference between T1 and T3(P凶0.05). The yield per mu increased significantly, but T1 and T3 did not increase significantly.

\section{Effects of different concentration treatments on the quality of cassava tuber blocks}

\section{Influence of different concentration treatments on water content of root tubers}

Starch content is an important indicator for quality evaluation of cassava. Cassava with a high starch content is highly suitable for deep processing industries such as starch processing. Our study showed that the use of soil amendments changed the starch content, and the starch content gradually decreased with the increase of the application concentration, but there was no substantial difference between groups on the whole. The water content of treated cassava root tuber varied by treatment (Table 2). Relative to T4, a decrease in water content was shown in T2 and T3, of which T2 was greatest, with a decrease of $5.96 \%$. In T1, the water content increased by $1.1 \%$. Moreover, the dry matter content of T2 also increased substantially (an increase by $5.95 \%$ relative to $\mathrm{T} 4$ ).

Table 2

Effects of different concentrations on the water content of root tubers

\begin{tabular}{|llll|}
\hline Treatment & Water content (\%) & Dry matter (\%) & Starch content (\%) \\
\hline T1 & $71.70 \pm 1.49^{a}$ & $28.30 \pm 1.49^{b}$ & $65.66^{b} \pm 14.93^{a}$ \\
\hline T2 & $64.64 \pm 2.72^{b}$ & $35.36 \pm 2.72^{a}$ & $63.51^{a} \pm 18.28^{a}$ \\
\hline T3 & $68.93 \pm 0.72^{a b}$ & $31.07 \pm 0.72^{a b}$ & $59.06^{a} \pm 7.21^{a}$ \\
\hline T4 & $70.60 \pm 3.43^{a}$ & $29.40 \pm 3.43^{b}$ & $76.12^{b} \pm 26.56^{a}$
\end{tabular}

Note: The values in the table are mean \pm standard deviation; Different lowercase letters in the same column represent significant differences at the $\mathrm{P}<0.05$ level.

\section{Influence of different concentration treatments on starch content of root tubers}

As shown in Table 2, the root starch content changed after treatment with different dosages of the modified preparation. It decreased in all three treatments, with a decrease of $13.74 \%, 16.57 \%$ and $22.41 \%$ in $\mathrm{T} 1, \mathrm{~T} 2$ and $\mathrm{T} 3$, respectively, but there was no considerable difference among the treatment groups.

Effects of different concentration treatments on the nutrient components of root tubers 
The mineral content of cassava directly indicates the tapioca edible nutritional value, which is crucial to inform the breeding of good varieties in the future. Under the action of soil amendment, the mineral content of cassava showed a rising trend overall, including $\mathrm{K}$ as one of the highest levels of mineral elements in cassava showed increased substantially.

As shown in Table 3, the contents of ash, Fe, K, Mg, Mn and Zn in T1 all increased, and Zn increased by $38.40 \%$ relative to compared with T4, whereas $\mathrm{Ca}$ and $\mathrm{Na}$ decreased by $5.03 \%$ and $7.75 \%$, respectively. The contents of ash, $\mathrm{K}, \mathrm{Mg}$ and $\mathrm{Zn}$ in T2 increased, with Mg increasing by $48.85 \%$ and $\mathrm{Ca}, \mathrm{Fe}, \mathrm{Mn}$ and $\mathrm{Na}$ all decreasing. The decrease of Fe was considerable at $29.46 \%$. Only the content of Mn decreased by $7.64 \%$ in T3, and all the other components showed increases, for example, ash, $\mathrm{K}$ and $\mathrm{Mg}$ contents increased by $53.29 \%, 48.64 \%$ and $45.29 \%$, respectively.

Table 3

Effects of different concentrations on the nutritional components of cassava

\begin{tabular}{|c|c|c|c|c|c|c|c|c|}
\hline Treatment & Ash Content (\%) & $\mathrm{Ca}(\mathrm{mg} / \mathrm{kg})$ & $\mathrm{Fe}(\mathrm{mg} / \mathrm{kg})$ & $\mathrm{K}(\mathrm{mg} / \mathrm{kg})$ & $\mathrm{Mg}(\mathrm{mg} / \mathrm{kg})$ & $\mathrm{Mn}(\mathrm{mg} / \mathrm{kg})$ & $\mathrm{Na}(\mathrm{mg} / \mathrm{kg})$ & $\mathrm{Zn}(\mathrm{mg} / \mathrm{kg})$ \\
\hline \multirow[t]{2}{*}{ T1 } & $2.17 \pm$ & $1010.68 \pm$ & $17.57 \pm$ & $6274.98 \pm$ & $403.26 \pm$ & $25.19 \pm$ & $81.02 \pm$ & $17.95 \pm$ \\
\hline & $0.40^{a}$ & $236.58^{a}$ & $5.87^{a}$ & $1068.54^{a}$ & $23.06^{a}$ & $13.42^{a}$ & $15.65^{a}$ & $2.58^{a}$ \\
\hline \multirow[t]{2}{*}{ T2 } & $1.85 \pm$ & $992.25 \pm$ & $8.98 \pm$ & $5608.66 \pm$ & $468.60 \pm$ & $16.32 \pm$ & $85.59 \pm$ & $13.24 \pm$ \\
\hline & $0.70^{a}$ & $9.29^{a}$ & $0.18^{b}$ & $875.36^{a}$ & $101.65^{a}$ & $2.35^{a}$ & $15.11^{a}$ & $2.14^{a b}$ \\
\hline \multirow[t]{2}{*}{ T3 } & $2.56 \pm$ & $1093.73 \pm$ & $12.78 \pm$ & $7310.04 \pm$ & $457.41 \pm$ & $22.38 \pm$ & $112.03 \pm$ & $18.09 \pm$ \\
\hline & $0.71^{a}$ & $264.57^{a}$ & $4.61^{a b}$ & $1263.50^{a}$ & $111.15^{a}$ & $7.62^{a}$ & $43.91^{a}$ & $1.60^{a}$ \\
\hline \multirow[t]{2}{*}{ T4 } & $1.67 \pm$ & $1064.24 \pm$ & $12.73 \pm$ & $4917.95 \pm$ & $314.82 \pm$ & $24.23 \pm$ & $87.83 \pm$ & $12.97 \pm$ \\
\hline & $0.65^{a}$ & $490.71^{a}$ & $3.64^{a b}$ & $1784.21^{a}$ & $72.08^{a}$ & $5.09^{a}$ & $21.41^{a}$ & $3.26^{b}$ \\
\hline
\end{tabular}

Note: The values in the table are mean \pm standard deviation; Different lowercase letters in the same column represent significant differences at the $\mathrm{P}<0.05$ level.

There were differences in the contents of the same element among the three treatments, but most of them were not significant (Pख0.05); only Fe and Zn showed significant changes. The Fe content in T2 was significantly reduced by $29.46 \%$, whereas it was significantly increased by $38.20 \%$ in T1. The Zn content in T1 and T3 was significantly increased by $38.40 \%$ and $39.48 \%$, respectively.

\section{Effects of different amendment concentrations on microbial diversity of cassava Sequencing and microbial community alpha diversity}

A total of 858918 and 1772862 valid sequences from bacteria and fungi were identified from soil samples respectively (all samples consist of 4 treatments $\times 2$ parts $\times 3$ biological replicates). On average, 71576.5 bacterial and 73869.25 fungal sequences were identified from each sample of soil. At a similar level of $97 \%$, The bacterial sequences were clustered into 21910 OTUs, an average of 1825.8 OTUs were generated from per soil sample (Table 4), with classification results of OTUs are 21 phyla and 347 genus. While the fungal sequences were clustered into 11377 OTUs, an average of 474.04 OTUs were generated from per soil sample (Table 5), with a total of 10 distinct fungal phyla and 528 genus were detected across all samples. 
Table 4

The Bacterial Information of Sample

\begin{tabular}{|llll|}
\hline Sample & Barcode & Seq Num & OTU Num \\
\hline S-T1A & CGCATA & 70369 & 1911 \\
\hline S-T1B & CTTGTA & 53037 & 1691 \\
\hline S-T1C & GTTTCG & 57834 & 1812 \\
\hline S-T2A & CTCCTG & 67933 & 1959 \\
\hline S-T2B & GTCGGA & 76894 & 1909 \\
\hline S-T2C & ATCGTT & 81898 & 1769 \\
\hline S-T3A & AATATC & 80327 & 1792 \\
\hline S-T3B & AAGCTC & 83767 & 1864 \\
\hline S-T3C & TTCCAT & 72515 & 1962 \\
\hline S-T4A & TCTAGG & 78135 & 1773 \\
\hline S-T4B & CTATAC & 71972 & 1767 \\
\hline S-T4C & GTCCCA & 64237 & 1701 \\
\hline
\end{tabular}

Table 5

The Fungal Information of Sample

\begin{tabular}{|llll|}
\hline Sample & Barcode & Seq Num & OTU Num \\
\hline S-T1A & TACGACA & 66379 & 780 \\
\hline S-T1B & TGTGCTA & 53308 & 745 \\
\hline S-T1C & TCACTCG & 62442 & 795 \\
\hline S-T2A & AGTCGTC & 57529 & 799 \\
\hline S-T2B & AGAGCAG & 71977 & 725 \\
\hline S-T2C & AGCTCTA & 67898 & 768 \\
\hline S-T3A & AGTATAC & 61032 & 623 \\
\hline S-T3B & AGTGCGA & 58757 & 797 \\
\hline S-T3C & ACACACG & 65459 & 760 \\
\hline S-T4A & ACAGCGA & 71252 & 533 \\
\hline S-T4B & ACATACT & 69428 & 565 \\
\hline S-T4C & ACTCTCA & 50622 & 733 \\
\hline
\end{tabular}

The Shannon index curves indicated that a sufficient amount and quantity of sequencing data was obtained (Supplementary Fig. S1 and S2). Bacterial richness (abundance-based coverage estimator, ACE) and Chao index were used to estimate the abundance and $\alpha$ diversity of microorganisms. Through the analyses of alpha diversity (Chao, Ace) (Supplementary Fig. S3, S4, S5 and S6), we found that the diversity of bacteria in the soil samples was as following: T2 > T1 > T3 > T4, while the fungal diversity was dominated by $T 1$, and followed by $T 2$, T3, T4. Compared with the control group, the experimental group had higher microbial diversity, and the soil samples treated with $\mathrm{T} 1$ concentration had the highest fungi richness. At the same time, the diversity of bacteria in T2 was the most abundant.

\section{The composition of bacterial and fungal communities}

The top ten bacterial phyla in the tested samples were Cyanobacteria_Chloroplast $\square$ Proteobacteria $\square$ Actinobacteria $\square$ Acidobacteria $\square C h l o r o f l e x i \square$ Firmicutes $\square$ Planctomycetes $\square$ Verrucomicrobia $\square$ Bacteroidetes $\square$ Candidate_division_WPS-2. Among them, the dominant bacteria phyla in all soil samples were Proteobacteria $\square$ Acidobacteria $\square$ Actinobacteria and Chloroflexi (Relative abundance > 10\%), accounting for 17.8-22.1\%, 16.0-17.6\%, 17.1-19.8\%, and 11.0-13.6\%, respectively (Fig. 3). And the top ten fungi phyla in the tested samples were Ascomycota,Basidiomycota $\square$ Glomeromycota $\square$ Mortierellomycota $\square$ Mucoromycota $\square$ Chytridiomycota $\square$ Zoopagomycota $\square$ Kickxellomycota $\square$ Rozellomycota and Blastocladiomycota (Fig. 4). Among them, the dominant fungi phyla in all soil samples were Ascomycota and Basidiomycota, accounting for $80.3 \%$ and $12.9 \%$, respectively. (Relative abundance $>10 \%$ ). 
Under different concentration treatment, at the genus level, the heatmap indicated that Gp1 was the most abundant bacteria in the soil, followed by unclassfied_Ktedonobacterales and Gp3. Among them, the relative abundance of Streptophyta was substantially higher in T2 than that of other concentration treatments, accounting for about $7.3 \%$ of the identified sequences. As for fungi, the composition differed greatly between the groups after treatment with different concentrations, and the samples under different concentration treatments contained more than 20 species of peculiar fungi. In addition, at the fungal genus level, the relative abundance of unclassfied_Chaetomiaceae in the treatment group was considerably lower than that of T4, and the relative abundance of Psathyrella in the T1 increase substantially compared to other treatment groups (Fig. 5,6).

Venns show us the unique bacterial genus of T2 was Fimbriimonas, the unique bacterial genus of T3 was Candidatus_Procabacter and Propionibacterium, and $\mathrm{T} 1$ had no unique bacterial genus. The composition of soil fungal genus differed greatly between the groups after treatment with different concentrations, and the samples under different concentration treatments contained more than 20 species of peculiar fungi. (Fig. 7,8).

At the genus level, we performed a statistical analysis on the soil bacteria and fungi communities of different treatments, using the default logarithm (LDA) value of 2 to identify a total of 11 different bacterial groups and 16 unique fungal species (Supplementary Fig. S7, S8). The T1 bacteria was characterized by the presence of unclassfied_Chitinophagaceae [LDA $(\log 10)>2.0]$.The characteristics of the T2 were Nocardioides and unclassfied_Spartobacteria [LDA $(\log 10)>2.0]$. The T3 was characterized by the presence of Microvirga, unclassfied_Chloroplast and Bacillariophyta [LAD $(\log 10)>2.0]$. Compared with bacteria, fungi show greater difference in LDA value.

\section{The community structure of bacterial and fungal communities}

The PCoA map based on the Bray-Curtis distance (Supplementary Fig. S9, S10) showed that bacteria and fungi communities from treated soil samples $(T 1, T 2, T 3)$ are clearly separated from the control group (T4), respectively, explaining the $47.31 \%$ and $36.95 \%$ of the total variation.

\section{Discussion}

\section{Growth-promoting effect of the amendment on cassava}

Cassava has been recognized as the best biomass energy crop in tropical and subtropical regions of China, and is one of the key crops for the development of biomass energy strategy in the "11th Five-Year Plan." It is an important goal of cassava cultivation to improve plant growth potential, root tuber yield and starch content ${ }^{34,35}$. In this paper, we found that amendment with Chinese herbal compound amendment powder, bacteriostatic agent and compound soil antivirals have a positive effect on the cassava plant growth. Various physiological indexes increased after using amendment, relative to T4, particularly in plant height, stem diameter, maximum circumference, plant tuber number and area yield. The physiological indexes increased may because the soil amendment powder can effectively improve soil structure, enrich soil nutrients and increase soil microbial activity, thus promoting the growth and yield of cassava plants ${ }^{36}$. In addition, some plant rhizosphere growth-promoting microorganisms in the soil also release plant hormones, such as indole acetic acid (IAA), abscisic acid (ABA), cytokinin (CTK) and gibberellin (GA), and some strains also promote plant growth by regulating ethylene levels ${ }^{37,38,39,40,41}$.

The root moisture content of cassava also substantially changed after the application of amendment powder and water. T2 was the lowest among the three treatments, while T1 showed a relative increase. In terms of root starch content, there was a decrease in all three treatments with the increase of the concentration of the improver, and the lowest value was reached when the application concentration was $1500 \mathrm{~kg} / \mathrm{hm}^{2}$. The decrease of water content in root tubers may have occurred because soil amendment powder and water agent changed the water and fertilizer utilization rate of the plant, improved the absorption and conversion efficiency of soil nutrients, and thus increased the transformation and accumulation of dry matter in the plant ${ }^{10}$.

\section{Effects of the amendment on nutrient indexes of cassava root tubers}

The contents of most mineral elements, such as $\mathrm{K}, \mathrm{Ca}, \mathrm{Na}, \mathrm{Mg}$ and $\mathrm{Mn}$, changed following treatment. According to the above experimental results, T3 had the best effect in terms of the content of root tuber nutrients. This was probably because soil amendment powder contains a high ionic charge and can thus carry out ion exchange while increasing soil fertility, improve soil permeability to a certain extent and finally enhance nutrient accumulation. This supports the results of $\mathrm{Yue}^{42}$.

Moreover, spraying Chinese herbal compound bacteriostatic agent and antiviral water agent may change the structure of soil microbial community around the plant, such as beneficial bacteria and harmful bacteria. Studies have also shown that microorganisms determine soil nutrients, and increasing numbers of scientists have begun to apply microbial activity as an index to measure soil fertility ${ }^{43}$. For example, lactic acid bacteria and yeast can promote the transformation of nutrients in soil, enabling them to be absorbed by plants and participate in the nutrient cycle ${ }^{44}$.

\section{Effects Of The Amendment On Microbial Diversity Of Cassava}


Through experiments, we found that the cassava plants in the T2 treatment group had great improvements in both phenotype and physiological indicators compared with other treatments. We further analyzed the bacterial abundance of the soil samples. It was found that in each treatment group Streptophyta is the dominant bacterial genera in T2 soil samples. Streptophyta was greatly important in forming biological soil crust,. Biological crusts played an essential components in forming arid and semi-arid ecosystems as they fix nitrogen and carbon, and enhance soil fertility 45 .

Fimbriimonas is a unique genera of T2, and the abundances of Nocardioides and unclassfied_Spartobacteria in the T2 group were greatly different from those of other treatment groups. Shen et al. carried out redundancy analysis and Spearman correlation analysis on bananas and showed that Spartobacteria and other bacteria are dominant in bananas treated with high-concentration biological fertilizers, and it was positively correlated with soil $\mathrm{pH}$, total nitrogen, total carbon and available phosphorus content. It was negatively correlated with the incidence of banana Fusarium wilt 46 . Chen found that the abundance of Nocardioides was positively correlated with the biomass accumulation and available phosphorus content of winter wheat during soil experiments on winter wheat ${ }^{47}$. At the same time, Fimbriimonas also had the characteristics of nitrogen fixation and denitrification, and played an important role in maintaining nitrogen balance ${ }^{48}$. All this showsed that the dominant or unique bacteria in $\mathrm{T} 2$ can affect the content of nutrient elements in the soil to regulate plant growth. In addition, when Liu studied the soil microbial mechanism of resistance to root rot in sugar beet varieties, they also found that the relative abundance of Nocardioides in samples with less disease was substantially increased compared with samples with more severe disease ${ }^{49}$. This may be because the presence of Nocardioides can enhance the ability of plants to resist diseases.

The author speculates that these advantages and the existence of unique bacteria can affect rhizosphere soil microorganisms, further improve soil effective nutrients and enzyme activities, and increase plant stress resistance, thereby affecting the growth and physiological indicators of cassava plants.

\section{Necessity of cassava topdressing}

Cassava has a strong ability to absorb water and fertilizer, and scientifically informed fertilization in continuous cropping will lead to a decrease in soil fertility and the field production of cassava ${ }^{50}$, which is often considered to be a strong fertilizer consumption ${ }^{51}$. The decrease in soil fertility leads to the unsustainable productivity of the cassava agro-ecosystem ${ }^{36}$. However, cultivation of casava doesn't need to apply base fertilizer. Putthacharoen suggested that fertilization does not need to be applied to cassava in the first two years of continuous cropping in newly reclaimed land $^{52}$. However, fertilization should be applied to medium fertility soil or two years after continuous cropping. In addition to the application of chemical fertilizer as base fertilizer, Luo showed that the application of $600-750 \mathrm{~kg} / \mathrm{hm}^{2}$ bio-organic fertilizer increased the yield of fresh tubers by 57.3-74.8\% compared with an unfertilized treatment, and promoted the growth of cassava stem and leaves, the transport and accumulation of assimilates to the underground part, and improved the yield of root tuber and the starch content ${ }^{53,54}$. However, excessive fertilization of cassava should be avoided, as the fertilizer utilization rate is low and excessive fertilization will lead to enhanced growth of the aboveground part and is not conducive to the formation of root tuber yield ${ }^{55}$. Studies have shown that the tuber starch content presents a parabolic change with the increase of nitrogen application rate ${ }^{56}$. Therefore, topdressing in the cultivation should be paid more attention to meet the nutrient requirements of cassava root tuber in the formation and expansion stages. Therefore, the use of Chinese herbal compound soil amendment powder as topdressing fertilizer could help to meet the demand of cassava growth economically and efficiently.

Our findings indicate that $1200 \mathrm{~kg} / \mathrm{hm}^{2}$ treatment at the intermediate level performs best, and staged fertilization is conducive to reducing fertilizer waste and improving recovery efficiency, which is consistent with the research results of Luo ${ }^{55}$ and Sangakkara ${ }^{57}$. Zhang showed that the application amount of $\mathrm{N}, \mathrm{P}$ and $\mathrm{K}$ had no significant effect on the starch content of the tubers ${ }^{58}$. In the current study, the traditional Chinese herbal soil amendment powder used included rice bran as the main source of organic nutrients, and Artemisia annua, A. argyi and other medicinal materials, which are safe and non-toxic. It can also be used in combination with reduced chemical fertilizer or organic fertilizer, which can significantly improve crop yield quality and increase the cassava Se content. This is consistent with the Guizhou research team's results for tomato, strawberry, tea, R. pseudostellariae and Pinellia ternata crops from 2018 to 2020 . Under the condition that most chemical agents were replaced by Chinese herbal compound bacteriostasis agent and antiviral water agent by spraying or irrigation root, $900-1200 \mathrm{~kg} / \mathrm{hm}^{2} \mathrm{Chinese}$ herbal compound soil amendment powder per mu could significantly improve crop yield and quality.

\section{References}

1. Zhang Q, Li GL, Yu YH, Jing MC. Analysis on the status quo and development of cassava deep processing in China. Cereal Feed Industry 01: 3134 (2017).

2. Shan WQ, Shang LM, Wang XM. Present situation and development strategy of cassava in Hainan province. Tropical Agricultural Engineering, 37 (3): 15-19 (2013). 
3. Wu BS,Wei JS, Wu M, He P, Wu GW, Wang GH, Gao L. Effects of environmental - friendly soil conditioner applied to cassava planting land in hainan province. Chinese Journal of Tropical Agriculture 12: 10-15 (2018).

4. Zhang BB, Guo JB, Jiang KY, Jia ZL, Wu YQ. Effects of Arkadolith soil amendment on the growth and sand soil improvement of Poplar. Bulletin of Soil and Water Conservation 31 (4): 191-194 (2011).

5. Bai XM, Zhang WT, Zhang QW, Hu GQ. Effect of soil ameliorant on yield increase and salt control in cotton field in northern Xinjiang. Jiangsu Agriculture and Sciences 48 (11): 77-81 (2020).

6. Urra, J., Mijangos, I., Lanzén, A., Lloveras, J., Garbisu, C., 2018. Effects of corn stover management on soil quality. Eur. J. Soil Biol. 88, 57-64 (2002).

7. Yu DD, Jia LM, Li Y, Jia ZK, Ma LY, Li M. Effect of Different Soil Conditioner on Soil Properties and Physiological Characteristics of Ginkgo biloba in the Abandon. Journal of Northeast Forestry University 43(9): 56-61 (2015).

8. Dominic H, Josef B, Enzo F, et al. Comparison of compost standards within the EU, North America and Australasia., Banbury:The Waste and Resources Action Programme (2002).

9. Yuan Y, Guo JB, Chen ZH, Cao YB, Yu ZS. Effects of self-made multifunctional soil conditioners on soil properties and the growth of Juglans regia. Science of Soil and Water Conservation 13 (3): 69-75 (2015).

10. Yuan Y, Guo JB, Yin SM. Effect of soil conditioner on the growth of Lolium multiflorum. ACTA Prataculturae Sinica 24 (10): $206-213$ (2015)区

11. Mangwandi C. Development of a value-added soil conditioner from high shear co-granulation of organic waste and limestone powder. Powder Technology 252: 33-41 (2014).

12. Wang RY, Wang SS, Pan WD, Li QC, Xia ZL, Guan ES, Zheng MQ, Pang GZ, Yang YJ, Yi ZJ. Strategy of tobacco plant against black shank and tobacco mosaic virus infection via induction of PR-1, PR-4 and PR-5 proteins assisted by medicinal plant extracts. Physiological and Molecular Plant Pathology 101: 127-145 (2018).

13. Torsvik V , Øvreås L. Microbial diversity and function in soil: from genes to ecosystems. Curr Opin Microbiol 5:240.

14. Fierer N, Jackson RB. The diversity and biogeography of soil bacterial communities. Proc Natl Acad Sci USA 103:626 (2006).

15. Zak DR, Holmes WE, White DC, Peacock AD, Tilman D. Plant diversity, soil microbial communities, and ecosystem function: are there any links? Ecology 84:2042 (2003).

16. Mondini, C., Sequi, P. Implication of soil C sequestration on sustainable agriculture and environment. Waste Manag. 28, 678-684 (2008).

17. Diacono, M., Montemurro, F. Long-term effects of organic amendments on soil fertility. A review. Agron. Sustain. Dev. 30, 401-422 (2010).

18. Urra, J., Mijangos, I., Lanzén, A., Lloveras, J., Garbisu, C. Effects of corn stover management on soil quality. Eur. J. Soil Biol. 88, 57-64 (2018).

19. Chojnacka, K., Gorazda, K., Witek-Krowiak, A., Moustakas, K. Recovery of fertilizer nutrients from materials - contradictions, mistakes and future trends. Renew. Sust. Energ. Rev. 110, 485-498 (2019).

20. Julen Urraa, Itziar Alkortab, Anders Lanzéna, Iker Mijangosa, Carlos Garbisu. The application of fresh and composted horse and chicken manure affects soil quality, microbial composition and antibiotic resistance. Applied Soil Ecology. 135, 73-84 (2019).

21. Liu CZ, Wang LC, Ouyang F, Ye HC, Li GF. Advances in artemisinin biosynthesis. Natural Product Research And Development 12 : $83-86$. https://doi.org/10.16333/j.1001-6880.2000.01.018 (2000).

22. Lyden J, Teasdale JR, Chen PK..Allelopathic activity of annul wormwood: artemisia annua and the role of artemisinin. Weed Sci 45 : $807-811$ (1997).

23. Chen PK, Leather GR. Plant growth regulatory activities of artemisinin and its related compounds. J of Chemical Ecology 16: $1867-1876$. https://doi.org/1007/BF01020500 (1990).

24. He J, Wang SG, Ding W. Study on allelopathic effects of alcohol extracts from artemisia annual. Journal of Southwest Agricultural University (Natural Science) 3: 281-284, 288 (2004).

25. Wang DM, Chen XF, Mai LW, Yang X, Lin R, Li QF. Study on the relationship between antioxidant capacity and total flavonoids contents of cassava leaves. Food Research And Development 42 (02): 37-43 (2021).

26. Zheng MQ, Wang RY, Wang DP, Pan WD, Liu XL, Yang Y, Li CY, Li Z, Xiao ML, Zhang Z. Effect of Traditional Chinese Medicine Antiviral Compounds on Virus Controlling, Yield and Quality of Radix Pseudostellariae. Chinese Agricultural Science Bulletin 36 (4): 123-129 (2020).

27. Dethlefsen, L., and Relman, D. A.. Incomplete recovery and individualized responses of the human distal gut microbiota to repeated antibiotic perturbation. P. Natl. Acad. Sci. USA 1(Suppl. 1), 4554-4561. doi: 10.1073/pnas.1000087107 (2011).

28. Dethlefsen, L., and Relman, D. A.. Incomplete recovery and individualized responses of the human distal gut microbiota to repeated antibiotic perturbation. P. Natl. Acad. Sci. USA 1(Suppl. 1), 4554-4561. doi: 10.1073/pnas.1000087107 (2011).

29. Caporaso, J. G., Kuczynski, J., Stombaugh, J., Bittinger, K., Bushman, F. D., Costello, E. K., et al.. QIIME allows analysis of high-throughput community sequencing data. Nat. Methods 7, 335-336. doi: 10.1038/nmeth.f.303 (2010).

30. Cole, J. R., Chai, B., Farris, R. J., Wang, Q., Kulam-Syed-Mohideen, A. S., McGarrell, D. M., et al.. The ribosomal database project (RDPII):introducing myRDP space and quality controlled public data. Nucleic Acids Res. 35, D169-D172. doi: 10.1093/nar/gkl889 (2007). 
31. Zhao, Y., Xiong, Z., Wu, G., Bai, W., Zhu, Z., Gao, Y., et al.. Fungal endophytic communities of two wild Rosa varieties with different powdery mildew susceptibilities. Front. Microbiol. 9:2462. doi: 10.3389/fmicb.2018.02462 (2018).

32. Shade, A., and Handelsman, J. Beyond the Venn diagram: the hunt for a core microbiome. Environ. Microbiol. 14, 4-12. doi: 10.1111/j.14622920.2011.02585.x (2012).

33. Segata, N., Izard, J., Waldron, L., Gevers, D., Miropolsky, L., Garrett, W. S., et al.. Metagenomic biomarker discovery and explanation. Genome Biol. 12:R60. doi: 10.1186/gb-2011-12-6-r60 (2011).

34. Wei CH, He Q, Li TT, Zhang T, He TG, Mo CE, Wei JH, Li ZY, Zeng XY, Huang WB. Effects of fertilization-tillage technology integration on nutrient accumulation and distribution囚and starch content of cassava. Journal of Southern Agriculture 47 (5): $632-637$ (2016).

35. Luo XL, Fan WJ. Constraints and strategies for enhancing cassava industry of guangxi. Journal of Agriculture 5 (8): 119-125 (2015).

36. Li J, Chen XL, Mao YF, Feng CY, Qin XD. Advances of research on the soil and water conservation of cassava cultivation. Chinese Journal Of Tropical Agriculture 31 (11): 17-22 (2011).

37. Ma Y, Luo YM, Teng Y. Rhizosphere growth-promoting bacteria and their application in phytoremediation of contaminated soil. ACTA Pedologica Sinica 5: 1021-1031 (2013).

38. Penrose DM, Glick BR. Levels of ACC and related compounds in exudate and extracts of canola seeds treated with ACC deaminase-containing plant growth-promoting bacteria. Canadian Journal of Microbiology 47(4): 368-372. https://doi.org/10.1007/s002840010101 (2001).

39. Zheng WB, Shen F, Yan XM, et al. Screening and identification of growth promoting bacteria with indole acetic acid and phosphorolytic effect in red soil and their growth promoting effect. Soils 47:361-368 (2015).

40. Li J, Ovakim DH, Charles TC, Trevor CC,Bernard RG. An ACC deaminase minus mutant of Enterobacter cloacae UW4 No longer promotes root elongation. Current microbiology 41(2), 101-105. https://doi.org/10.1007/s002840010101 (2000).

41. Yuan RW, Liu L, Zhang R, Fan SY. The interaction mechanism between plant rhizosphere secretion and soil microbe: a review. Chinese Agricultural Science Bulletin 36(2): 26-35 (2020).

42. Yue ZW, Wang BT, Wang HL, et al.. Application of compound nutrition long-effect fertilizer and water-retaining agent and its slow-release fertilizer - saving effect. Transactions of the CSAE 27 (8): 56-62 (2011).

43. Connell L,Redman R, Craig S, Rodriguez Distribution and abundance of fungi in the soils of Taylor Valley, Antarctica. Soil Biology and Biochemistry 38(10): 3083-3094. https://doi.org/10.1016/j.soilbio.2006.02.016 (2006).

44. Dalal RC, Henderson PA, Glasby JM. Organic matter and microbial biomass in a vertisol after 20 years of zero-tillage.Soil Biology and Biochemistry 23: 435-441. https://doi.org/10.1016/0038-0717(91)90006-6 (1991).

45. Rippin M, Borchhardt N, Karsten U, \&Becker B. Cold Acclimation Improves the Desiccation Stress Resilience of Polar Strains of Klebsormidium (Streptophyta). Frontiers in Microbiology 10: 19. http://doi.org/10.3389/fmicb.2019.01730 (2019).

46. Shen ZZ, Ruan YZ, Wang BB Zhong ST, Su LX, Li rong, Shen QR. Effect of biofertilizer for suppressing Fusarium wilt disease of banana as well as enhancing microbial and chemical properties of soil under greenhouse trial. Applied Soil Ecology 93: 111-119. http://doi.org/10.1016/j.apsoil.2015.04.013 (2015).

47. Chen MQ, Xu JS, Li ZQ, Zhao BZ, Zhang JB. Soil physicochemical properties and bacterial community composition jointly affect crop yield. Agronomy Journal 112 (5): 4358-4372. https://doi.org/1002/agj2.20358 (2020).

48. Liang ZZ, Deng JQ, Wang ZK, Shen YY, Wang XZ. Differences in soil bacterial community composition among three forage-crop rotations on the Longdong Loess Plateau. ACTA Prataculturae Sinica 26 (8): 180-191 (2017).

49. Liu H, Dong YH, Sui YY, Li JG. Soil Microbial Mechanism of Disease Resistant Sugar Beet Variety. Chinese Agricultural Science Bulletin 37(15):78-86 (2021).

50. Lin HX, Yuan ZQ, Liu RG, Xiao YP, Wang RQ. Advance in high-yielding cultivation of cassava and disposal of plant waste after its harvest. Acta Agriculturae Jiangxi 23 (02): 30-32. https://doi.org/10.19386/j.cnki.jxnyxb.2011.02.008 (2011).

51. Zhang YH, Zheng HG, Guan YZ, Li DR. Summarization of research on nutritional characteristics and fertilizer of Cassava. Guangdong Argricutural Sciences (10): 29-31 (2009).

52. Putthacharoen S, Howeler RH, Jantawat S, Vichukit Nutrient uptake and soil erosion losses in cassava and six other crops in a Psamment in eastern Thailand. Field Crops Research 57 (01): 113-126. https://doi.org/10.1016/S0378-4290(97)00119-6 (1998).

53. Luo XL, Cen ZY, Pan YH, Liao C, Shao ZF. Studies on the effects of bio-organic fertilizer on the yield of cassava luo xinglu. Chinese Agricultural Science Bulletin 22 (6): 241-244 (2006).

54. Luo XL, Cen ZY, Xie HX, Pan YH, Liao C, Shao ZF, Chen HL. Effects of Bio-Organic Fertilizer on the Growth of Cassava and the Physical and Chemical Biological Character of Soil. ACTA Agriculturae Boreali-occidentalis Sinica 17 (1):167-173 (2008).

55. Luo LY, Xue XX, Wei YX, Huang J, Zhang YF, Zhao CM, Luo XH, Wang WB. Yield and nutrient absorption and utilization characteristics of cassava under reduced fertilizer application. Chinese Journal of Tropical Crops, https://kns.cnki.net/kcms/detail/46.1019.S.20210315.1752.005.html (2021). 
56. Jiang W, Wu Y, Yang JH, Song Y. Research progress on the effect of N, P and K application rate on cassava yield and quality. Chinese Horticulture Abstracts 31 (11): $72-76$ (2015).

57. Sangakkara, Wijesinghe D, B. Nitrogen fertilizer affects growth, yield, and N recovery in cassava (Manihot esculenta L. Crantz) Communications in Soil Science and Plant Analysis 45(8/11): 1446-1452. http://doi.org/1080/00103624.2014.904330 (2014).

58. Zhang J, Meng ML, Wang YH. Research progress on the effect of N, P and K application rate on cassava yield and quality. Crops (4): 124-127 (2012).

\section{Figures}

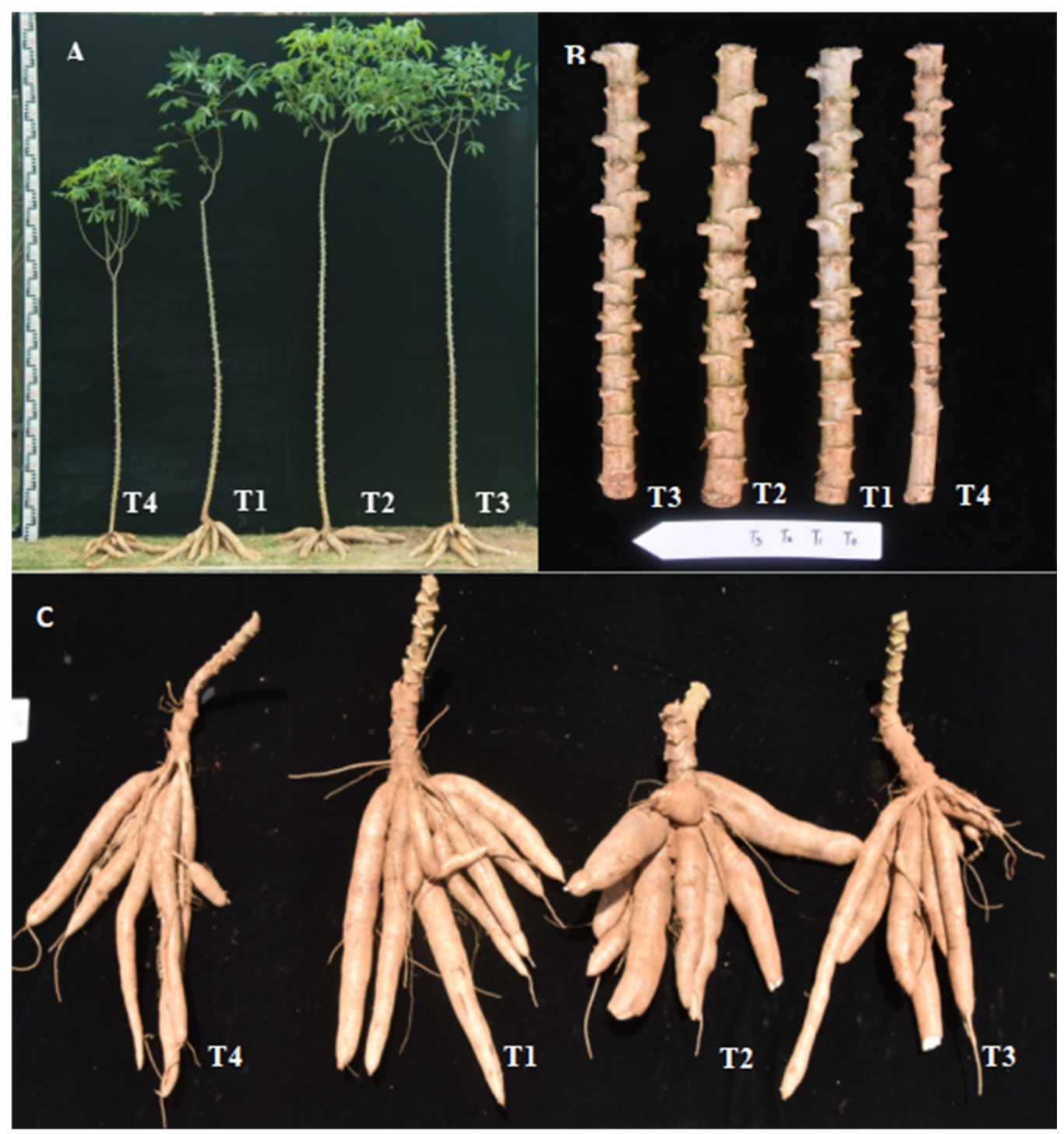

\section{Figure 1}

Photographs of cassava treated with different concentrations of Chinese herbal medicine. A: full plants, B: stems, C: tubers. The treatments were as follows: $900 \mathrm{~kg} / \mathrm{hm} 2$ soil improvement powder (topdressing) + bacteriostatic agent + antiviral agent (T1); $1200 \mathrm{~kg} / \mathrm{hm} 2 \mathrm{soil}$ improvement powder (topdressing) + bacteriostatic agent + antiviral agent (T2); $1500 \mathrm{~kg} / \mathrm{hm} 2$ soil improvement powder (topdressing) + bacteriostatic agent + antiviral agent (T3); and an unfertilized control (T4). 

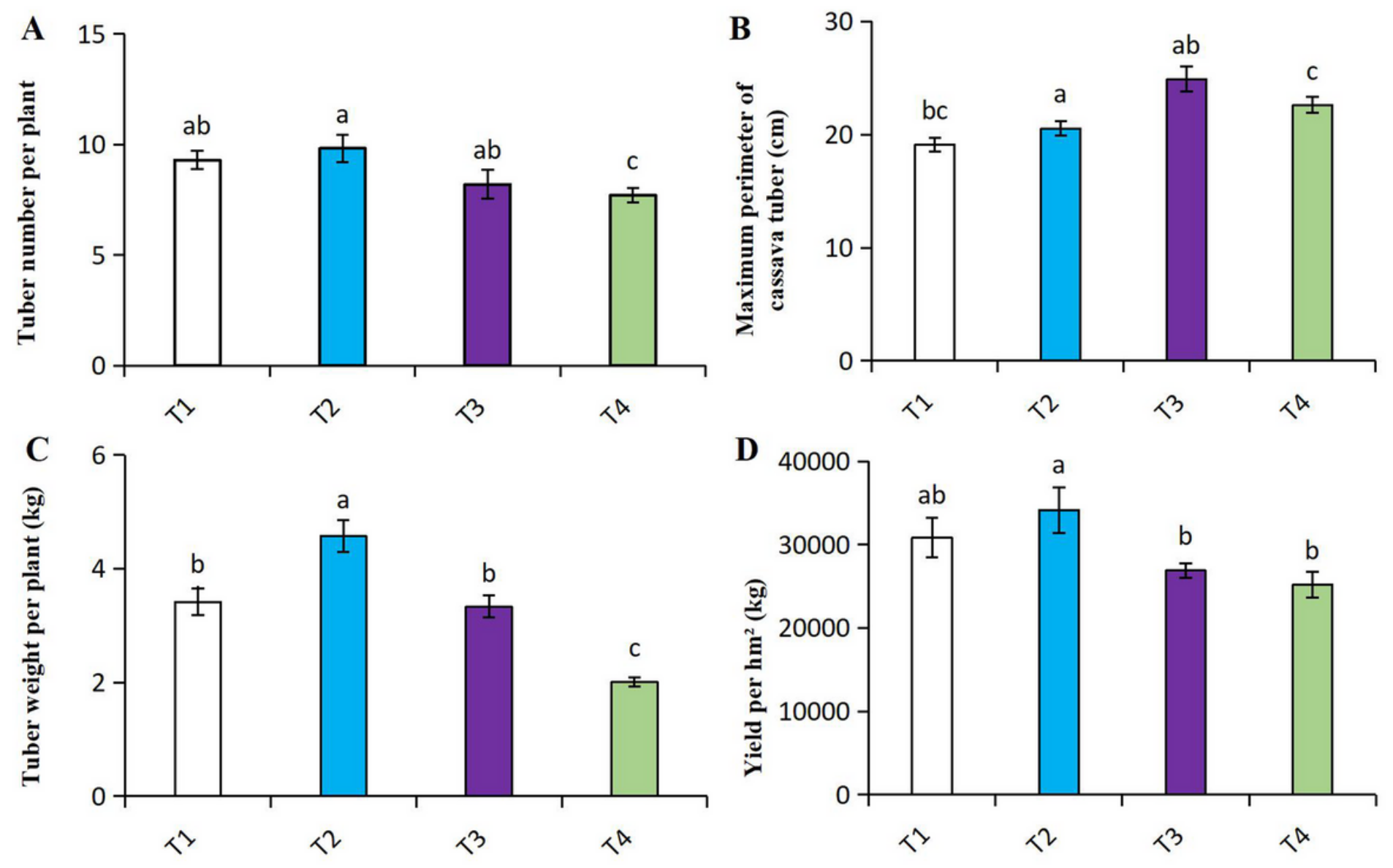

Figure 2

Effects of different treatments on physiological indexes of rhizomes of tubers (A: Tuber number per plant; B: Maximum perimeter of cassava tuber; C: Tuber weight per cassava plant; D: yield per hectare). The error bar was informed by standard error. Note: Different lowercase letters in the same column represent significant differences at the $\mathrm{P}<0.05$ level. The treatments were as follows: $900 \mathrm{~kg} / \mathrm{hm} 2$ soil improvement powder (topdressing) + bacteriostatic agent + antiviral agent (T1); $1200 \mathrm{~kg} / \mathrm{hm} 2$ soil improvement powder (topdressing) + bacteriostatic agent + antiviral agent (T2); 1500 $\mathrm{kg} / \mathrm{hm} 2$ soil improvement powder (topdressing) + bacteriostatic agent + antiviral agent (T3); and an unfertilized control (T4). 


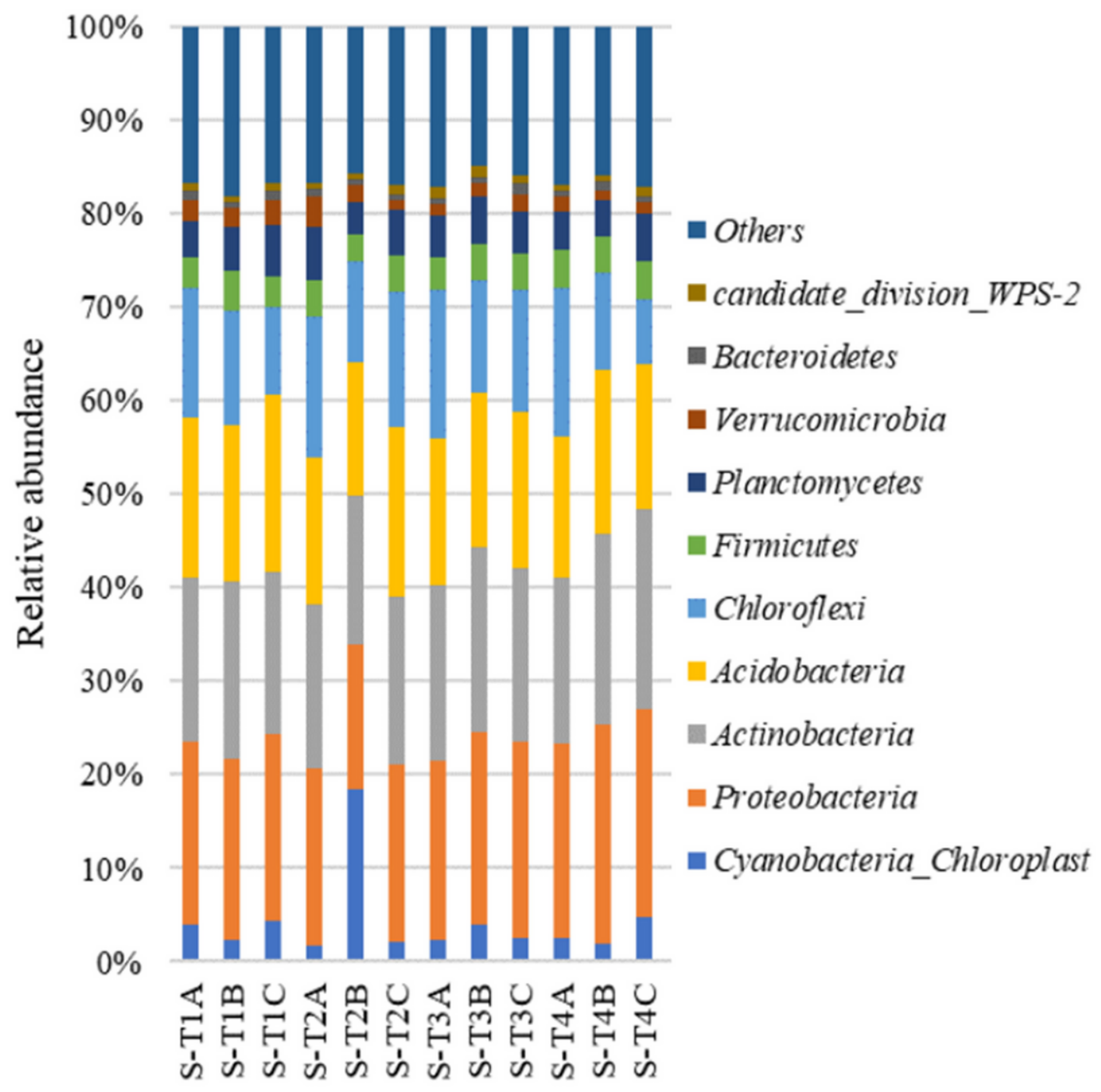

Figure 3

Histogram of the relative abundances at the phyla level of the TOP 10 bacterial communities 


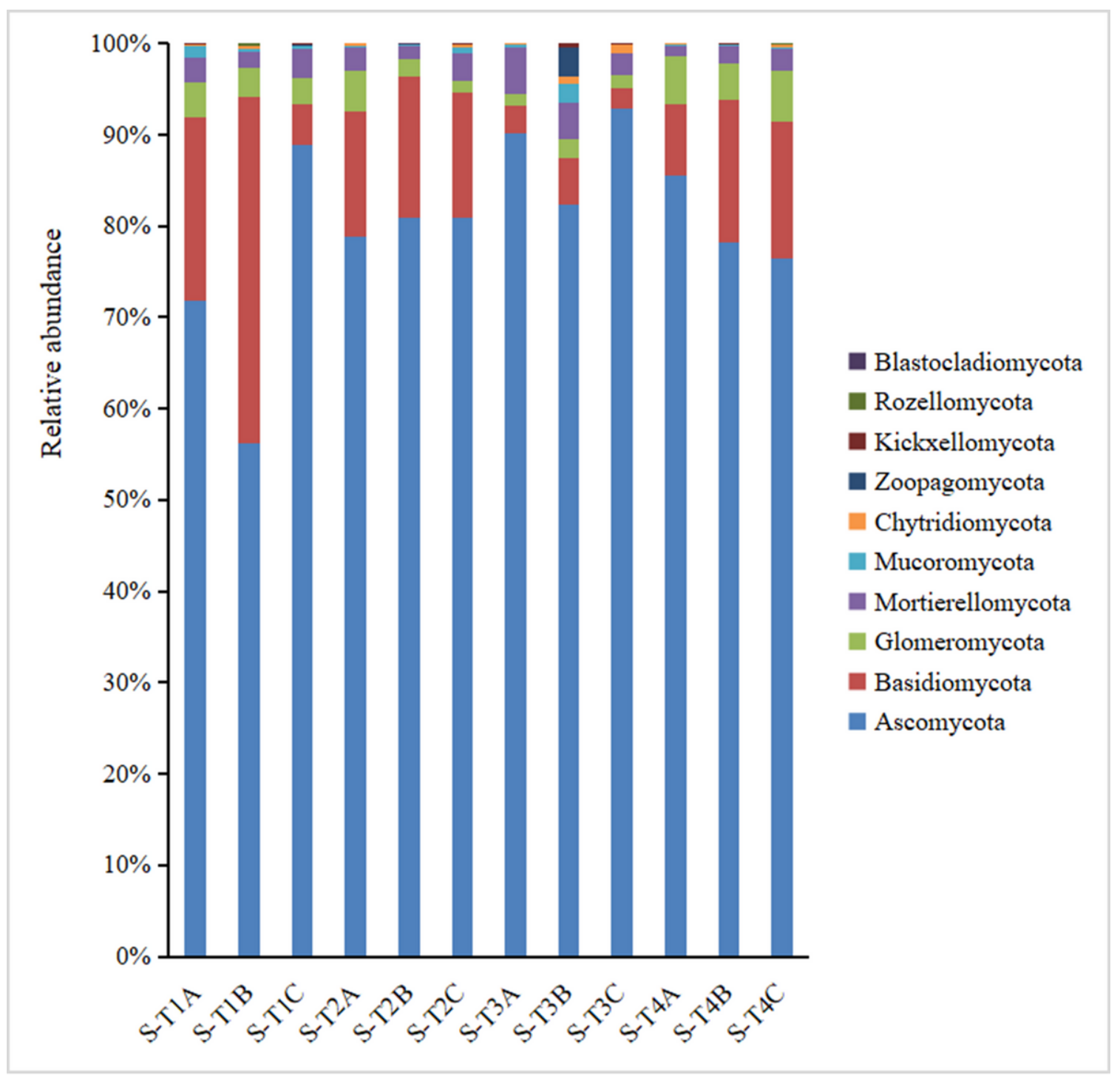

Figure 4

Histogram of the relative abundances at the phyla level of the TOP 10 fungal communities 


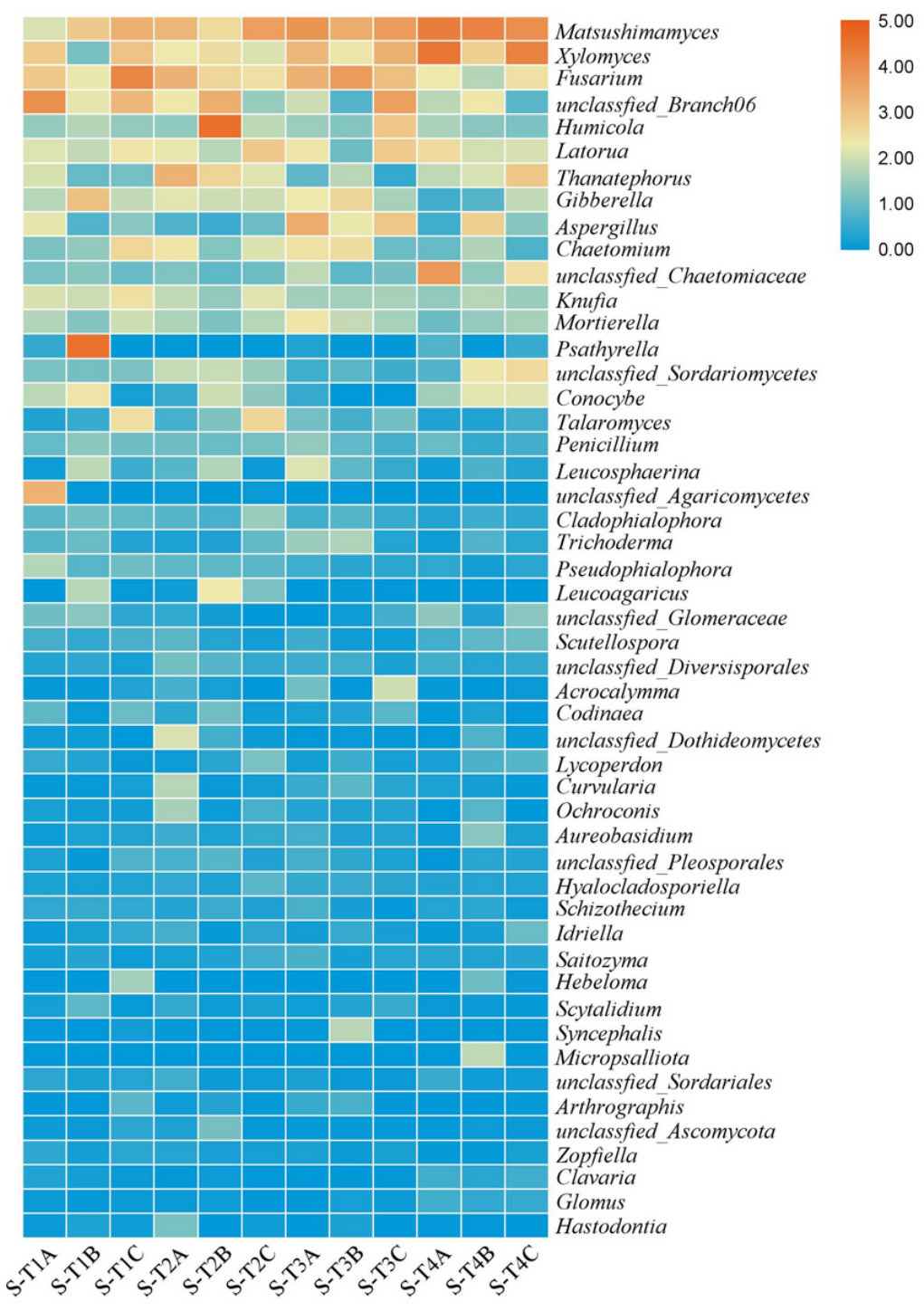

Figure 5

Heatmap of the relative abundances at the genus level of the TOP 50 bacterial communities in the soil 


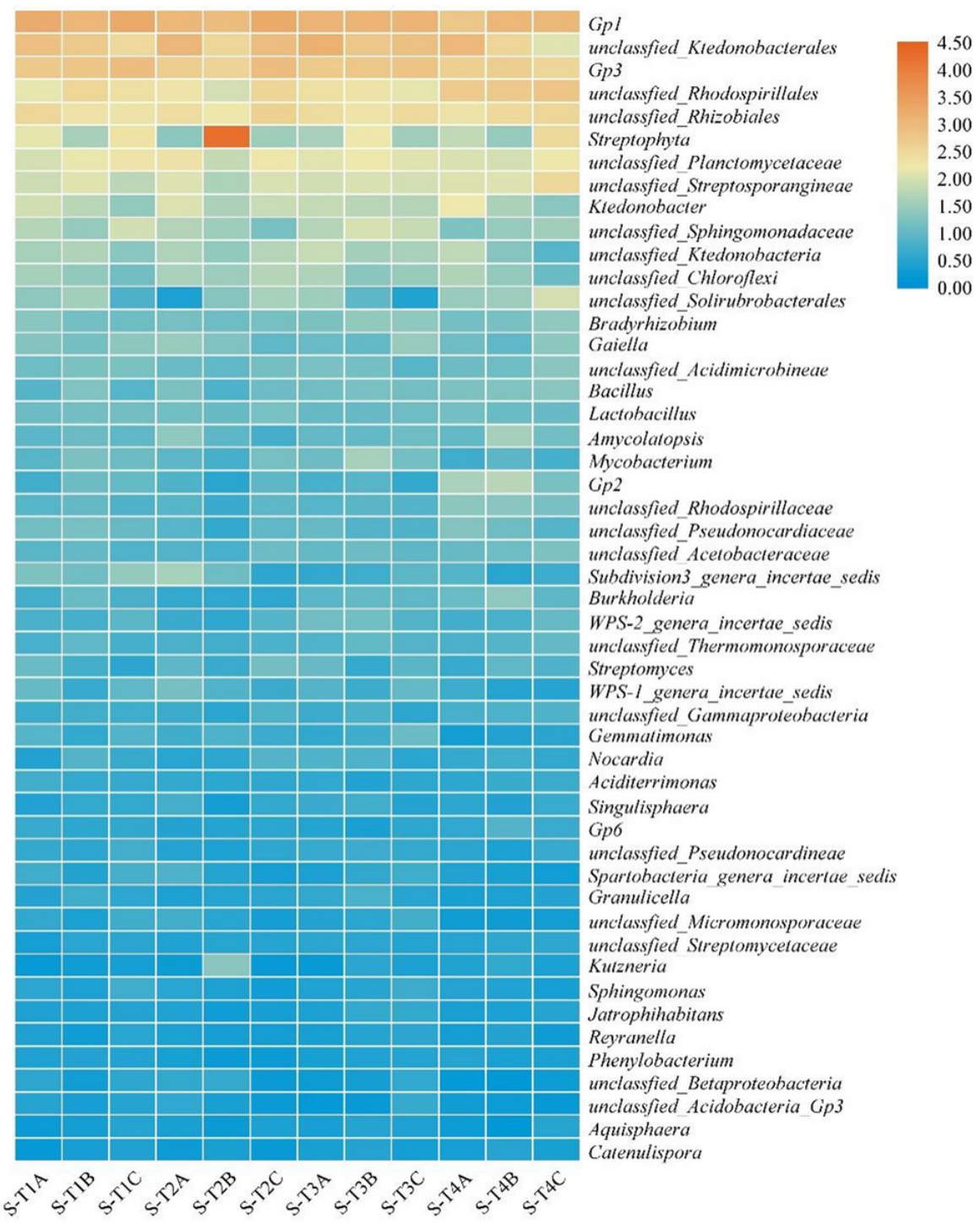

Figure 6

Heatmap of the relative abundances at the genus level of the TOP 50 fungal communities in the soil 


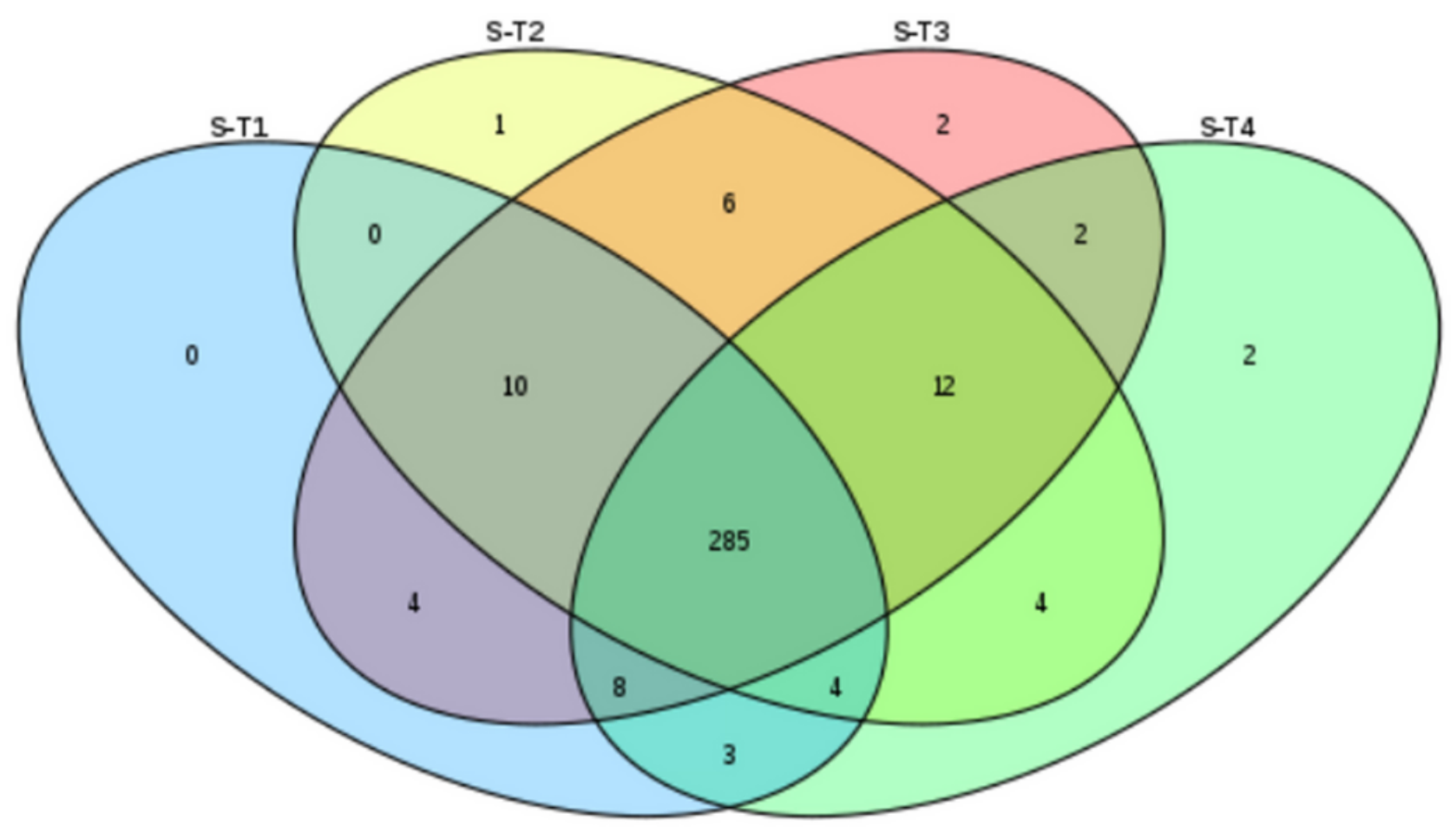

Figure 7

Number of bacterial genus in the soil 


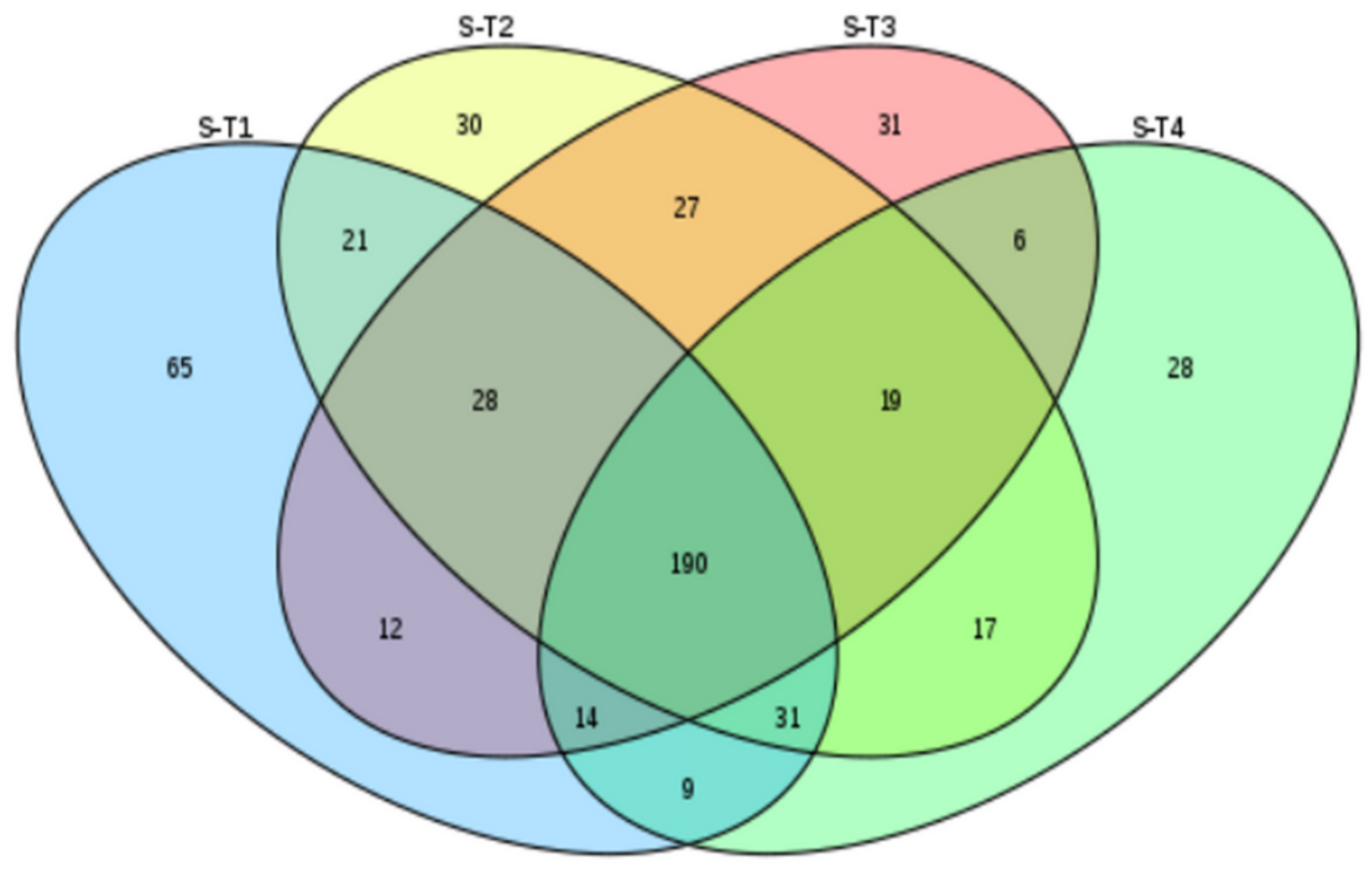

Figure 8

Number of fungal genus in the soil

\section{Supplementary Files}

This is a list of supplementary files associated with this preprint. Click to download.

- SupplementaryFig.docx 